\title{
THE EFFECT OF NITROGEN FERTILISERS ON THE GRAIN YIELD OF DIFFERENT CULTIVARS OF WINTER WHEAT
}

\author{
Ilona VAGUSEVIČIENĖ, Institute of Agricultural and Food Science, Aleksandras Stulginskis University, Studentų g. 11, Akademija \\ LT-53361, Kauno raj., Lithuania. i.vaguseviciene@gmail.com (corresponding author) \\ Aistė JUCHNEVIČIENĖ, Institute of Agricultural and Food Science, Aleksandras Stulginskis University, Studentų g. 11, Akademija
} LT-53361, Kauno raj., Lithuania. aiste.zuzaviciute@inbox.lt

\begin{abstract}
The article deals with the effect of nitrogen fertilizer on the yield of different cultivars of winter wheat. Field experiments were conducted in 2011-2013 at the Experimental Station of Aleksandras Stulginskis University in carbonate shallow gleyic leached soil, (Calc(ar)i-Epihypogleyic Luvisol). The object of the investigation was winter wheat cultivars 'Zentos' and 'Ada'. In sowing time the wheat was treated with granular superphosphate $\left(\mathrm{P}_{60}\right)$ and potassium chloride $\left(\mathrm{K}_{60}\right)$, and in spring, after the vegetative growth had resumed, in tillering time $(\mathrm{BBCH} 23-15)$ with ammonium nitrate $\left(\mathrm{N}_{60}\right)$. Additionally, foliar fertilizer urea solution was used: $\mathrm{N}_{30}, \mathrm{~N}_{40}$ at booting stage (BBCH 34-36) and $\mathrm{N}_{15}, \mathrm{~N}_{30}$ at milk ripening stage (BBCH 71-74). It has been established that application of nitrogen fertilizer at booting and milk ripening stages increased the yield of wheat cultivars 'Zentos' and 'Ada' (0.06-1.74 and 0.41-1.74 $\left.\mathrm{t} \mathrm{ha}{ }^{-1}\right)$. The correlation and regression analysis confirmed that wheat grain yield statistically significantly correlated with nitrogen fertilizer application rates. The correlative relationships were very strong $(r=0.983$ and $r=0.987)$. Irrespective of additional fertilization, genetic properties of the cultivars also had influence on the yield.
\end{abstract}

Keywords: yield, nitrogen fertilizer, winter wheat.

\section{INTRODUCTION}

According to overall production, wheat is the most common crop in the world after rice and corn. Annually, more than $600 \mathrm{~m}$ tons of it is grown for food and feed (Shewry, 2009). Nitrogen is the most important fertiliser necessary for plant growth and the production of biomass (Lian-peng et al., 2012; Murozuka et al., 2014).

Meteorological conditions in Lithuania are not favourable to have an ample and good quality winter wheat yield each year. Therefore ways are sought to optimise the process of plant nutrition, especially with nitrogen. The effect of nitrogen on wheat, with foliar fertilisation, also depends heavily on the time of fertiliser application (Maikštenienè et al., 2006).

For winter crops nitrogen is necessary throughout the whole period of their vegetation. However, at different development stages the effect of $\mathrm{N}$ on the formation of grain yield varies (Diekmann and Fishbeck, 2005). The greatest amount of nitrogen is required at the $5^{\text {th }}-7^{\text {th }}$ stages of organogenesis process (at booting - seedling growth stages). This is the time of intensive cell division as well as the metabolism of proteins and other biologically active substances (Fageria et al., 2006; Šlapakauskas ir Duchovskis, 2008). Having optimised wheat nutrition with nitrogen, in tillering time more shoots develop, at booting stage more productive stems are formed and after flowering protein content in grain increases (Maikštennienè et al., 2006; Leliūnienè et al., 2013; Vagusevičienė et al., 2013).

Winter wheat growing conditions and productivity change, depending upon climate change (Lazauskas et al., 2012). Crop can suffer not only from long-term but also from short-term adverse meteorological conditions (Gelvonauskis et al., 2000; Šabajevienè et al., 2008; Lukatkin et al., 2012). The yield losses incurred due to climate change can be reduced by correctly selecting plants or their cultivars and by applying appropriate growing technologies (Brazaityte et al., 2008; Duchovskis et al., 2015).

Plant yield potential is fully exhausted under favourable environmental conditions (Long et al., 2006; Zhu et al., 2008). Both the demand for nitrogen and maximum yield are genetically programmed (Balogh et al., 2007), therefore it is necessary to choose not only the fertiliser application rates optimal for a certain cultivar, but also fertilisation strategies optimal for different climatic conditions (Tranavičienè, 2009).

The aim of the work is to investigate the effect of nitrogen fertiliser on the grain yield of different cultivars of winter wheat.

\section{MATERIALS AND METHODS}

The investigation was carried out during the period between 2011 and 2013, at the Experimental Station of Aleksandras Stulginskis University. The object of the research: cultivars of winter wheat 'Zentos' (Germany) and 'Ada'

Copyright (C) 2015 The Authors. Published by Aleksandras Stulginskis University. This is an open-access article distributed under the terms of the Creative Commons Attribution License (CC-BY 4.0), which permits unrestricted use, distribution, and reproduction in any medium, provided the original author and source are credited. 
(Lithuania). The soil: carbonate shallow gleyic leached soil, (IDg8-k) Calc(ar)i-Epihypogleyic Luvisol (LVg-p-w-cc). According to the values of agrochemical indicators, over the research years the soil was neutral and weakly alkaline $\left(\mathrm{pH}_{\mathrm{KCl}}\right.$ 7.0-7.2) with medium humus content (2.48-2.70\%) and high phosphorus (271.0-296.8 $\left.\mathrm{mg} \mathrm{kg}^{-1} \mathrm{P}_{2} \mathrm{O}_{5}\right)$ and potassium content (178.0-184.0 $\left.\mathrm{mg} \mathrm{kg}^{-1} \mathrm{~K}_{2} \mathrm{O}\right)$.

The two-factor field experiment was conducted in five variants with four replications, factor A being winter wheat cultivars and factor B - nitrogen fertilizer application rates. Total plot size of the experiment was $40 \mathrm{~m}^{2}(4 \times 10)$ and harvested plot size was $20 \mathrm{~m}^{2}(2 \times 10)$. The plots were arranged in random order.

Winter rape was the preceding crop of winter wheat. Autumn ploughing $(25 \mathrm{~cm}$ in depth), cultivation, harrowing, sowing and the application of phosphorus and potassium fertilisers $\left(\mathrm{P}_{60} \mathrm{~K}_{60}\right)$ were major tasks to set up the experiment. The seeding rate was 4.5 million fertile seeds per ha ${ }^{-1}$. The sowing process was performed by seeding machine Kverneland Accord m-drill, $3.5 \mathrm{~cm}$ in the soil.

Granular superphosphate $\left(\mathrm{P}_{60}\right)$ and potassium chloride $\left(\mathrm{K}_{60}\right)$ fertilisers were spread during sowing, while ammonium nitrate $\left(\mathrm{N}_{60}\right)$ in spring, in tillering time (BBCH 23-25), after the vegetation had resumed. Additionally, the plants were treated with foliar fertilizer urea solution: $\mathrm{N}_{30}, \mathrm{~N}_{40}$ at booting stage (BBCH 34-36) and $\mathrm{N}_{15}, \mathrm{~N}_{30}$ at milk ripening stage (BBCH 71-74).

The scheme of the experiment:

Factor A (winter wheat cultivars):

1. 'Zentos'

2. 'Ada'

Factor B (nitrogen fertilizer application rates):

1. Control $-\left(\mathrm{P}_{60} \mathrm{~K}_{60}\right)$ in sowing time $+\mathrm{N}_{60}$ in tillering time (Background).

2. Background $+\mathrm{N}_{30}$ at booting stage $+\mathrm{N}_{15}$ in milk ripening stage.

3. Background $+\mathrm{N}_{30}$ at booting stage $+\mathrm{N}_{30}$ in milk ripening stage.

4. Background $+\mathrm{N}_{40}$ at booting stage $+\mathrm{N}_{15}$ in milk ripening stage.

5. Background $+\mathrm{N}_{40}$ at booting stage $+\mathrm{N}_{30}$ in milk ripening stage.

The system of plant protection against diseases and weeds was applied. The winter wheat was sprayed with herbicides (BBCH 19-20 and BBCH 27), fungicides (BBCH 37 and $\mathrm{BBCH}$ 65-67) as well as growth regulators (BBCH 32 and $\mathrm{BBCH} 37)$.

The meteorological conditions of the experiment are described according to the registered data of Noreikiškès based Kaunas Meteorological Station. In 2011 September was warm and humid. The monthly average of the month was $13.6^{\circ} \mathrm{C}\left(1.4^{\circ} \mathrm{C}\right.$ higher than the multi annual average). The monthly precipitation exceeded the multi average of September by $20.1 \mathrm{~mm}$. The level of moisture $(\mathrm{HTC}-1.81)$ and warmth after the sowing was favourable for the germination and development of winter wheat. The temperature close to multi annual averages prevailed until the middle of November. December was unusually warm. The average temperature reached $1.9{ }^{\circ} \mathrm{C}$. January was warmer than usual, while February was $5.5^{\circ} \mathrm{C}$ colder than the multi annual average. The beginning of March was dominated by wintry weather $\left(-1.2-5.2^{\circ} \mathrm{C}\right)$. A period of spring-like weather started from the second decade of the month. The average temperature in April reached $7.7^{\circ} \mathrm{C}$; the level of precipitation was $72.3 \mathrm{~mm}$. Over the rest of the vegetative period of the plants the temperature remained close to multi annual averages. However, the amount of precipitation varied considerably: it was either higher or lower than the multi annual averages. The wheat was harvested on 2 August.

In 2012 wheat was sown on 17 September. The average temperature of the month was $12.2{ }^{\circ} \mathrm{C}$, close to the multi annual average. Monthly precipitation exceeded multi annual September average by $13.2 \mathrm{~mm}$. the wheat sprouted well and evenly, took root, and their vegetation period continued until the middle of November. Although the winter was not warm, the crop wintered well. The vegetation of the plants resumed in the middle of April. The average temperature of the month reached $5.5^{\circ} \mathrm{C}\left(1.2^{\circ} \mathrm{C}\right.$ lower than the multi annual $)$; the precipitation was $56.5 \mathrm{~mm}$. May was warm and humid enough (HTC - 1.28). The average temperature reached $16.1{ }^{\circ} \mathrm{C}\left(3.5^{\circ} \mathrm{C}\right.$ higher than the multi annual). The average temperature in June was $18.5^{\circ} \mathrm{C}$ (close to the multi annual average). The precipitation was $45.9 \mathrm{~mm}$ (HTC -0.83 ). The weather in July was changeable. In the first decade of the month there was only $1.5 \mathrm{~mm}$ of rainfall, and the average temperature was $19.1{ }^{\circ} \mathrm{C}$. The second decade was marked by heavy rain $(79.8 \mathrm{~mm})$, and the average temperature was $17.6^{\circ} \mathrm{C}$. The precipitation during the third decade reached $37.2 \mathrm{~mm}$, and the average temperature again reached $19.1{ }^{\circ} \mathrm{C}$. On 31 July the wheat had reached hard dough maturity and was thrashed.

The methods of the agrochemical analyses of the soil: soil $\mathrm{pH}_{\mathrm{KCl}}$ - potentiometric, $1 \mathrm{~N} \mathrm{KCl}$ extract (LST ISO 10390:2005); organic carbon (C), \% - Tyurin (ISO 10694:1995); humus, \% - calculated by multiplying the amount of carbon by a factor of 1.724; mobile phosphorus $\left(\mathrm{P}_{2} \mathrm{O}_{5}\right)$ and potassium $\left(\mathrm{K}_{2} \mathrm{O}\right), \mathrm{mg} \mathrm{kg}^{-1}$ - Egner-Riehm-Domingo (A-L) (GOST 26208-84).

The stages of wheat development are presented according to BBCH scale (Meier, 1997).

The harvest of wheat crop has been calculated by a computerized weighing system in the combine harvester. Crop yield has been recalculated with crop moisture being $14 \%$ and the crop being absolutely clean.

Statistical processing of the yield data has been performed using dispersive analysis method ANOVA, software package SELEKCIJA. Dispersive analysis of two factor data has been employed (Tarakanovas ir Raudonius, 2003). Correlation and regression have been calculated with software program STATISTIKA 7 (Hill and Levicki, 2005).

The symbols used in the article:

* - statistically significant, when, respectively, the degree of probability is $95 \%(P<0.05)$; 
** - statistically significant, when, respectively, the degree of probability is $99 \%(P<0.01)$;

$(P>0.05)$ - no significant differences;

$\mathrm{LSD}_{05}$ - margin of significant disparity when the degree of probability is $95 \%$; $\mathrm{LSD}_{01}$ - margin of significant disparity when the degree of probability is $99 \%$.

\section{RESULTS AND DISCUSSION}

One of the most important and effective factors leading to an increase in yield and improvement of quality indicators is application of nitrogen fertilizer (Ehdaie and Waines, 2001; Acevedo et al., 2002; Mašauskas and Mašauskienė, 2002).

In each year of the experiment winter wheat grain yield rose due to nitrogen fertilizer used at booting and milk ripening stages. In 2012 treatment of 'Zentos' plants with $\mathrm{N}_{30}+\mathrm{N}_{15}, \mathrm{~N}_{30}+\mathrm{N}_{30}, \mathrm{~N}_{40}+\mathrm{N}_{15}$ and $\mathrm{N}_{40}+\mathrm{N}_{30}$ fertiliser application rates increased the yield $\left(0.06-0.55 \mathrm{t} \mathrm{ha}^{-1}\right)$, as compared to control plot plants; the rise was not considerable $(P>0.05)$ (Table 1$)$.

Table 1. Winter wheat yield $\left(\mathrm{t} \mathrm{ha}^{-1}\right), 2012-2013$

\begin{tabular}{|c|c|c|c|c|c|}
\hline \multirow{2}{*}{$\begin{array}{c}\text { Winter wheat } \\
\text { cultivars } \\
\text { (Factor A) }\end{array}$} & \multicolumn{5}{|c|}{ Nitrogen fertilizer application rates (Factor B) } \\
\hline & $\mathrm{N}_{60}+\mathrm{N}_{0}+\mathrm{N}_{0}$ & $\mathrm{~N}_{60}+\mathrm{N}_{30}+\mathrm{N}_{15}$ & $\mathrm{~N}_{60}+\mathrm{N}_{30}+\mathrm{N}_{30}$ & $\mathrm{~N}_{60}+\mathrm{N}_{40}+\mathrm{N}_{15}$ & $\mathrm{~N}_{60}+\mathrm{N}_{40}+\mathrm{N}_{30}$ \\
\hline \multicolumn{6}{|c|}{2012} \\
\hline 'Zentos' & 6.88 & 6.94 & 7.21 & 7.43 & 7.43 \\
\hline 'Ada' & 3.79 & 4.20 & 4.85 & 5.02 & 4.72 \\
\hline \multicolumn{6}{|c|}{$\mathrm{LSD}_{05} \mathrm{AxB}=0.745 ; \mathrm{LSD}_{01} \mathrm{AxB}=1.006$} \\
\hline \multicolumn{6}{|c|}{2013} \\
\hline 'Zentos' & 5.41 & 6.79 & 7.28 & 7.20 & 7.40 \\
\hline 'Ada' & 5.78 & 7.20 & 7.48 & 6.81 & 7.52 \\
\hline
\end{tabular}

The comparison of the yields of 'Zentos' wheat treated with different application rates $\left(\mathrm{N}_{30}+\mathrm{N}_{30}\right.$ with $\mathrm{N}_{30}+\mathrm{N}_{15}$, $\mathrm{N}_{40}+\mathrm{N}_{30}$ with $\mathrm{N}_{40}+\mathrm{N}_{15}, \mathrm{~N}_{40}+\mathrm{N}_{15}$ with $\mathrm{N}_{30}+\mathrm{N}_{15}$ and $\mathrm{N}_{40}+\mathrm{N}_{30}$ with $\mathrm{N}_{30}+\mathrm{N}_{30}$ ) did not reveal any significant differences $(P>0.05)$. The wheat of cultivar 'Ada' fertilized with $\mathrm{N}_{30}+\mathrm{N}_{30}$ and $\mathrm{N}_{40}+\mathrm{N}_{15}$ fertiliser application rates at booting and milk ripening stages produced a considerably bigger yield $\left(1.06-1.23 \mathrm{t} \mathrm{ha}^{-1}\right)(P<0.01)$, as compared to with control plot plants. A substantial addition to the yield $\left(0.93 \mathrm{tha}^{-1}\right)(P<0.05)$ was also achieved in the wheat treated with $\mathrm{N}_{40}+\mathrm{N}_{30}$ fertiliser application rate, in comparison to control plot plants. Fertilization with $\mathrm{N}_{30}+\mathrm{N}_{15}$ fertiliser application rate, as compared to unfertilized wheat, did not have any significant influence on the yield $(P>0.05)$. However, the yield was substantially improved $\left(0.82 \mathrm{t} \mathrm{ha}^{-1}\right)(P<0.05)$ by fertilisation with a higher $\left(\mathrm{N}_{40}\right)$ fertilizer application rate at booting stage, and with $\mathrm{N}_{15}$ fertiliser application rate at milk ripening stage, in comparison to the wheat treated with $\mathrm{N}_{30}+\mathrm{N}_{15}$ fertiliser application rate. The comparison of 'Ada' plants fertilized with different application rates $\left(\mathrm{N}_{30}+\mathrm{N}_{30}\right.$ with $\mathrm{N}_{30}+$ $\mathrm{N}_{15}, \mathrm{~N}_{40}+\mathrm{N}_{30}$ with $\mathrm{N}_{40}+\mathrm{N}_{15}$ and $\mathrm{N}_{40}+\mathrm{N}_{30}$ with $\mathrm{N}_{30}+\mathrm{N}_{30}$ ) did not show any significant effect of the fertilizer on the yield $(P>0.05)$. Irrespective of additional fertilization, wheat genotype influenced the yield. Cultivar 'Zentos' wheat in tillering time treated with $\mathrm{N}_{60}$ fertiliser application rate produced a substantially more copious $\left(3.09 \mathrm{t} \mathrm{ha}^{-1}\right)(P<0.01)$ harvest, as compared to 'Ada' wheat fertilized with the same application rate. 'Zentos' plants additionally treated with nitrogen fertilizer cropped considerably better $\left(2.36-2.74 \mathrm{t} \mathrm{ha}^{-1}\right)(P<0.01)$, in comparison to additionally fertilised 'Ada' wheat.

In 2013 cultivar 'Zentos' wheat yield was on average $5.0 \%$ lower, while that of 'Ada' $54.0 \%$ higher than in 2012 when the wheat was lodged due to unfavourable meteorological conditions. Additional fertilization at booting and milk ripening stages considerably increased $\left(1.38-1.99\right.$ and 1.03-1.74 $\left.\mathrm{t} \mathrm{ha}^{-1}\right)(P<0.01)$ 'Zentos' and 'Ada' yields, as compared to the plants in control plots. 'Zentos' wheat treated with $\mathrm{N}_{30}+\mathrm{N}_{30}$ application rates at booting and milk ripening stages cropped substantially more copiously $\left(0.49 \mathrm{t} \mathrm{ha}^{-1}\right)(P<0.05)$, as compared with the wheat fertilized with $\mathrm{N}_{30}+\mathrm{N}_{15}$ application rates. The yield was significantly improved $\left(0.41 \mathrm{t} \mathrm{ha}^{-1}\right)(P<0.05)$ by fertilization with a higher $\left(\mathrm{N}_{40}\right)$ application rate at booting stage, and with $\mathrm{N}_{15}$ application rate at milk ripening stage, in comparison to the wheat treated with $\mathrm{N}_{30}+\mathrm{N}_{15}$ application rate. Fertilization with $\mathrm{N}_{40}+\mathrm{N}_{30}$ application rate, as compared to the wheat treated with $\mathrm{N}_{40}+$ $\mathrm{N}_{15}$ application rate, did not have any significant impact on the yield $(P>0.05)$. No considerable improvement $(P>0.05)$ in the yield was established after the fertilisation with $\mathrm{N}_{40}+\mathrm{N}_{30}$ application rate, in comparison to the wheat treated with $\mathrm{N}_{30}+\mathrm{N}_{30}$ application rate. Fertilization with $\mathrm{N}_{40}+\mathrm{N}_{30}$ application rate at booting and milk ripening stages increased the yield considerably $\left(0.71 \mathrm{t} \mathrm{ha}^{-1}\right)(P<0.01)$ in 'Ada' plants, as compared to the wheat fertilized with $\mathrm{N}_{40}+\mathrm{N}_{15}$ application rate. The comparison of the yields of 'Ada' plants treated with different fertilizer application rates $\left(\mathrm{N}_{30}+\mathrm{N}_{30}\right.$ with $\mathrm{N}_{30}+\mathrm{N}_{15}$, $\mathrm{N}_{40}+$ $\mathrm{N}_{15}$ with $\mathrm{N}_{30}+\mathrm{N}_{15}$ and $\mathrm{N}_{40}+\mathrm{N}_{30}$ with $\left.\mathrm{N}_{30}+\mathrm{N}_{30}\right)$ no significant differences $(P>0.05)$ were established. The yield of cultivar 'Ada' wheat was not improved substantially $(P>0.05)$ by the fertilization with $\mathrm{N}_{60}$ application rate in tillering time, in comparison to 'Zentos' plants treated with $\mathrm{N}_{60}$ application rate. Genetic peculiarities of the cultivar did not manifest themselves. 'Ada' plants treated with $\mathrm{N}_{30}+\mathrm{N}_{15}$ application rate produced a considerably bigger harvest $\left(0.41 \mathrm{t} \mathrm{ha} \mathrm{C}^{-1}\right)(P<$ $0.05)$ than 'Zentos' wheat fertilized with the same fertilizer application rate. The cross-comparison of the yields of 'Ada' and 'Zentos' wheat treated with $\mathrm{N}_{30}+\mathrm{N}_{30}, \mathrm{~N}_{40}+\mathrm{N}_{15}$ and $\mathrm{N}_{40}+\mathrm{N}_{30}$ did not reveal any significant differences $(P>0.05)$. 
The correlation and regression analysis of the data showed that the yield of winter wheat statistically significantly depended on nitrogen fertilizer application rates (Fig. 1).

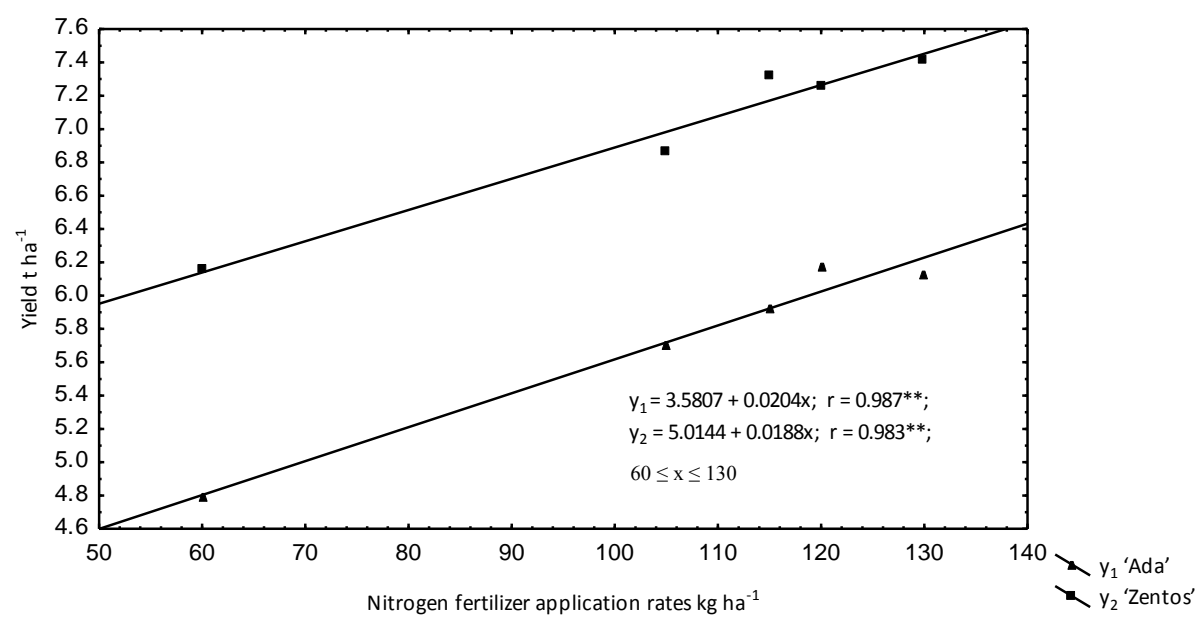

Figure 1. The dependence of winter wheat yield $\left(\mathrm{y}_{1}, \mathrm{y}_{2}, \mathrm{t} \mathrm{ha}^{-1}\right)$ on nitrogen fertilizer application rates $\left(\mathrm{x}, \mathrm{kg} \mathrm{ha}^{-1}\right), 2012-2013$ Note: $* *$ - statistically significant, when, respectively, the degree of probability is $99 \%(P<0.01)$

The dependence of the yield $\left(\mathrm{y}_{1}, \mathrm{y}_{2} ; \mathrm{t} \mathrm{ha}^{-1}\right)$ on nitrogen fertilizer application rates $\left(\mathrm{x} ; \mathrm{kg} \mathrm{ha}^{-1}\right)$ was best reflected by the following linear regression equations: $\mathrm{y}_{1}=3.5807+0.0204 \mathrm{x} ; \mathrm{y}_{2}=5.0144+0.0188 \mathrm{x}$. Correlative relations obtained were very strong $\left(r=0.987^{* *} ; r=0.983^{* *}\right)$.

Scientific literature states that the application of nitrogen fertilizer at late stages of development - after seedling growth - increases the concentration of nitrogen in the upper part of the plant, prolongs the vegetative growth of the flag leaf, activates the photosynthesis process and may even cause the renewal of micro-roots (Daniel and Triboi, 2000). It has been proved by different research that fertilization of winter wheat after flowering creates more favourable conditions for protein synthesis in the cells building grain mass (Lomoko, 1998). It is likely that the plants in our experiments assimilated nitrogen fertilizer directly, which contributed to the formation of larger yield.

\section{CONCLUSIONS}

Additional fertilization with nitrogen at booting and milk ripening stages increases wheat yield. The correlation and regression analysis shows that wheat yield statistically significantly depends on nitrogen fertilizer application rates. The dependence on fertilizer application rates is best described by linear regression equations. Correlative relationships obtained are very strong. Irrespective of additional fertilization, wheat genotype also has influence on the yield.

\section{REFERENCES}

1. Acevedo, E., Silva, P., Silva, H., 2002. Wheat growth and physiology. In: Curtis, B.C. (Ed.), Bread Wheat: Improvement and Production, FAO Plant Production and Protection Series No. 30. Rome, Italy, p. 567. http://www.fao.org/docrep/006/y4011e/y4011e00.htm

2. Balogh, A., Hornok, M., Pepo, P. 2007. Study of physiological parameters in sustainable winter wheat (Triticum aestivum L.) production. Cereal Research Communications, Vol. 35, Iss. 2 pp. 205-208. http://dx.doi.org/10.1556/CRC.35.2007.2.10

3. Brazaitytė, A., Juknys, R., Sakalauskaitè, J., Sakalauskienė, S., Lazauskas, S., Kučinskienė, E., Urbonavičiūtė, A., Samuolienė, G., Šabajevienė, G., Ulinskaite, R., Kviklys, D., Duchovskienė, L., Šikniašnianienė, J. B., Baranauskis, K., Duchovskis, P. 2008. Ecophysiological investigations under conditions of changing environment. Sodininkystè ir daržininkysté, Vol. 27, No. 3, pp. $263-276$.

4. Daniel, C., Triboi, E. 2000. Effects of temperature and nitrogen nutrition on the grain composition of winter wheat: effects on gliadin content and composition. Journal of Cereal Science, Vol. 32, Iss. 1 pp. 45-56. http://dx.doi.org/10.1006/jcrs.2000.0313

5. Diekmann, F., Fishbeck, G. 2005. Differences in wheat cultivar response to nitrogen supply. II: differences in N-metabolism related traits. Journal of Agronomy \& Crop Science, Vol. 191, Iss. 5, pp. 362-376. http://dx.doi.org/10.1111/j.1439-037X.2005.00166.x

6. Duchovskis, P., Brazaitytè, A., Samuolienè, G., Viršilè, A., Vaštakaite, V. 2015. Fotofiziologinių tyrimų būklè ir jų taikymo perspektyvos augalininkystėje: studija. Vilnius: LMA, 92 p. (in Lithuanian)

7. Ehdaie, B., Waines, J. G. 2001. Sowing date and nitrogen rate effects on dry matter and nitrogen partitioning in break and durum wheat. Field Crops Research, Vol. 73, Iss. 1, pp. 47-61. http://dx.doi.org/10.1016/S0378-4290(01)00181-2

8. Fageria, N. K., Baligar, V. C., Clark, R. B. 2006. Physiology of crop production. USA, 345 p.

9. Gelvonauskis, B., Duchovskis, P., Bandaravičienè, G. 2000. Investigation of winter hardiness and cold hardiness in apple progenies. Acta Horticulturae, Vol. 538, pp. 277-280. http://dx.doi.org/10.17660/ActaHortic.2000.538.48

10. Hill, T., Levicki, P. 2005. Statistics methods and applications. Madison, USA, 800 p.

11. ISO 10694:1995. Soil quality - Determination of organic and total carbon after dry combustion (elementary anglysis). 
12. Lazauskas, S., Povilaitis, V., Antanaitis, Š., Sakalauskaite, J., Sakalauskienė, S., Pšibišauskienè, G., Auškalnienè, O., Raudonius, S., Duchovskis, P. 2012. Winter wheat leaf area index under low and moderate input management and climate change. Journal of Food, Agriculture \& Environment, Vol. 10, Iss. 1, pp. 588-593.

13. Leliūnienè, J., Klimas, E., Samuolienè, G., Duchovskis, P. 2013. The influence of sowing time and fertilization on the assimilative leaf area formation of Festulolium. Rural Development 2013, Proceedings, Vol. 6, Iss. 2, pp. 111-114.

14. Lian-peng, L., Yuan-ying, L., Sheng-guo, L., Xian-long, P. 2012. Effects of Nitrogen Management on the Yield of Winter Wheat in Cold Area of Northeastern China. Journal of Integrative Agriculture, Vol. 11, Iss. 6, pp. $1020-1025$. http://dx.doi.org/10.1016/S2095-3119(12)60094-X

15. Lomoko, E. I. 1998. Vlijanie doz i srokov provedenija azptnych podkormok na urožaj I kačestvo ozimoj pšenicy. Agrochimija, Vol. 51, Iss. 11, pp. 90-103.

16. Long, S., Zhu, X. G., Naidu, S., Ort, D. 2006. Can improvement in photosynthesis increase crop yields? Plant, Cell and Environment, Vol. 29, Iss. 3, pp. 215-330. http://dx.doi.org/10.1111/j.1365-3040.2005.01493.xx

17. LST ISO 10390:2005. Dirvožemio kokybè. pH nustatymas (tapatus ISO 10390:1994). Vilnius: Lietuvos standartizacijos departamentas, $2005 \mathrm{~m}$.

18. Lukatkin, A. S., Brazaitytè, A., Bobinas, Ц̆., Duchovskis, P. 2012. Chilling injury in chilling-sensitive plants: a review. Zemdirbyste-Agriculture, Vol. 99, Iss. 2, pp. 111-124.

19. Maikštėnienè, S., Krištaponytė, I., Arlauskienė, A. 2006. Grain quality indicators of winter wheat varieties as affected by urea application through leaves. Zemdirbyste-Agriculture, Vol. 93, No. 3, pp. 141-157.

20. Mašauskas, V., Mašauskienè, A. 2002. The effect of the foliar-applied rates of urea-ammonium nitrate solution UAN-32 and timing on the yield parameters and grain quality of winter wheat. Zemdirbyste-Agriculture, Vol. 77, pp. 70-81.

21. Meier, U. 1997. Growth Stages of Mono- and Dicotyledonous Plants. BBCH Monograph. Berlin, Wien: Blackwell Wissenschaftsverlag. $622 \mathrm{p}$.

22. Murozuka, E., Laursen, K., Lindedam, J., Shield, I., Bruun, S., Magid, J., Møller, I., Schjoerring, J. 2014. Nitrogen fertilization affects silicon concentration, cell wall composition and biofuel potential of wheat straw. Biomass and Bioenergy, Vol. 64, pp. 291298. http://dx.doi.org/10.1016/j.biombioe.2014.03.034

23. Šabajevienè, G., Sakalauskienè, S., Lazauskas, S., Duchovskis, P., Urbonavičiūtè, A., Samuolienè, G., Ulinskaitė, R., Sakalauskaite, J., Brazaityte, A., Povilaitis, V. 2008. The effect of ambient air temperature and substrate moisture on the physiological parameters of spring barley. Zemdirbyste-Agriculture, Vol. 95, No. 4, pp. 71-80.

24. Shewry, P. R. 2009. Wheat. Journal of Experimental Botany, Vol. 60, Iss. 6, pp. 1537-1553. http://dx.doi.org/10.1093/jxb/erp058

25. Šlapakauskas, V., Duchovskis, P. 2008. Augalų produktyvumas. Klaipėda: IDP solutions, 253 p. (In Lithuanian)

26. Tarakanovas, P., Raudonius, S. 2003. Agronominių tyrimų duomenų statistinė analizė taikant kompiuterines programas ANOVA, STAT, SPLIT-PLOT iš paketo SELEKCIJA ir IRRISTAT. Akademija, Kauno r. 58 p. (In Lithuanian)

27. Tranavičienè, T. 2009. Azoto poveikis skirtingų paprastojo kviečio (Triticum aestivum L.) veislių fotosintezės ir grūdų kokybės rodikliams: daktaro disertacija. Akademija, 89 p. (In Lithuanian)

28. Vagusevičienè, I., Juchnevičiene, A., Duchovskis, P. 2013. The Effect of Nitrogen Fertilizers on the Changes of Photosynthetic Pigments in Winter Wheat. Rural Development 2013, Proceedings, Vol. 6, Iss. 2, pp. 266-269.

29. Zhu, X. G., Long, S., Ort, D. 2008. What is the maximum efficiency with which photosynthesis can convert solar energy into biomass? Current Opinion in Biotechnology, Vol. 19, Iss. 2, pp. 1-7. http://dx.doi.org/10.1016/j.copbio.2008.02.004 